Гарник Людмила Петрівна кандидат політичних наук, економістміжнародник, перекладач, магістр психології, Почесний професор i дослідник Міжнародного інституту миру та релігій (IPI), докторант, експерт відділу міжнародних зв'язків, Харківський національний технічний університет сільського господарства імені Петра Василенка, вул. Алчевських 44, м. Харків, 61002, тел.: (066) 327-20-49, e-mail: milla.garnyk@gmail.com, https://orcid.org/0000-0003-0983-9323.

Данченко Ірина Олексіївна доктор педагогічних наук, доцент, професор кафедри ЮНЕСКО «Філософія людського спілкування» та соціально- гуманітарних дисциплін, керівник Психологічної служби, Харківський національний технічний університет сільського господарства імені Петра Василенка, вул. Алчевських 44, м. Харків, 61002, тел.: (095)515-22-72, e-mail: irinadanchenko@khntusg.info, https://orcid.org/0000-0003-0103-8142.

Снігурова Ірина Іванівна філолог, викладач української мови та філологічних дисциплін, здобувач кафедри ЮНЕСКО «Філософія людського спілкування» та соціально- гуманітарних дисциплін, Харківський національний технічний університет сільського господарства імені Петра Василенка, вул. Алчевських 44, м. Харків, 61002, тел.: (066)806-60-90, e-mail: irinasnihurova71@gmail.com, https://orcid.org/0000-0002-9637-2428.

Вітковський Юрій Петрович доктор економічних наук, доцент, професор кафедри маркетингу й економіки, проректор 3 науково-педагогічної роботи та міжнародних зв'язків, Харківський національний технічний університет сільського господарства імені Петра Василенка, Афілійований професор Академії WSB (Польща), вул. Алчевських 44, м. Харків, 61002, тел.: (067)571-60-67, e-mail: vicerector@khntusg.info, https://orcid.org/0000-0001-5806-8671.

Аль-Халавані Хусамеддін Рамазанович кандидат політичних наук, докторант, Харківський національний технічний університет сільського господарства імені Петра Василенка, Керівник ГО «Центр міжнародних відносин «Мир і безпека», тел.: (068) 600-95-50, e-mail: husamhalawani@yahoo.com, https://orcid.org/0000-0002-2921-3013.

Шерстюк Валерій Сергійович кандидат технічних наук, доцент, Членкореспондент Української інженерної академії наук України, доцент кафедри Обладнання та інжинірингу переробних і харчових виробництв, Харківський національний технічний університет сільського господарства імені Петра Василенка, вул. Алчевських 44, м. Харків, 61002, тел.: (067)242-66-62, e-mail: sherstuk-v-s@ukr.net, https://orcid.org/0000-0002-1781-5009. 
Осінкн Олександр Олександрович аспірант кафедри транспортних технологій та логістики, Харківський національний технічний університет сільського господарства імені Петра Василенка, вул. Алчевських 44, м. Харків, 61002, тел.: (097)703-60-92, e-mail: aleksander_2020@ukr.net, https://orcid.org/0000-0002-6910-98-86.

\section{КОНКУРЕНТОСПРОМОЖНІСТЬ І РОЗВИТОК СПЕКТРУ ОСВІТНІХ ПОСЛУГ В УКРАЇНІ: ПСИХОЛОГО-ПЕДАГОГІЧНИЙ АСПЕКТ}

Анотація. Статтю присвячено висвітленню ключових психологопедагогічних і соціально-історичних факторів, що вплинули на поточний стан конкурентоспроможності й обсягів експорту освітніх послуг національними вишами, а також оцінці впливу національних реформ вищої освіти та причин

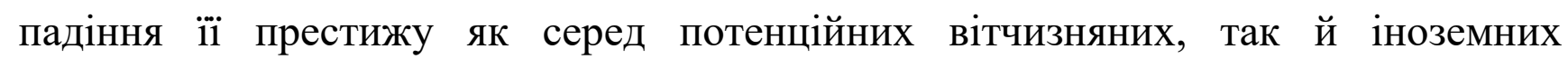
абітурієнтів. Також у статті наведено концептуальні засади розбудови толерантності в освітньому середовищі вишу як передумови соціальної інклюзії та інтернаціоналізації освітніх послуг, а також розвитку соціально- й культурно інтеграційного потенціалу українських регіональних вищих освітніх закладів у рамках визначеного урядом України курсу освітніх реформ і пов'язаних з ними інституційних та організаційних трансформацій.

Толерантність як організаційна цінність і чеснота освіченої особистості нівелює прояви інтолерантного ставлення до думки інших, невизнання унікальності й рівноцінності інших людей, несприйняття їх світогляду, а також неповагу до прав людини. Постійна міграція представників інших культур на територію нашої країни викликає в деяких співгромадян занепокоєння та страх перед можливим обмеженням їх «національної гідності». Відтінки цього побоювання різні: від індиферентності до агресії, від холодної байдужості до виявів ксенофобії (ненависті до представників іншої нації). 3 точки зору психології, такі прояви розглядаються як своєрідна гіперболізована захисна реакція на реальні або уявні загрози з боку представників інших культур та/або етнічних груп. Запропоновані психолого-педагогічні інструменти сприятимуть зниженню соціально-психологічної напруги в учасників освітнього процесу та серед широкого кола вітчизняних і міжнародних стейкхолдерів освітніх послуг.

Ключові слова: толерантність, соціально-культурний інтеграційний потенціал освітнього простору, якість освіти, виховання особистості.

Garnyk Liudmyla Petrivna $\mathrm{PhD}$ (Political Science), Master of Psychology, Postdoctoral Student, Expert of International Relations Department, Kharkiv Petro Vasylenko National Technical University of Agriculture, Honorary professor and research team member of IIPR, 44 Alchevskih St., Kharkiv, 61002, tel.: (066) 327-20-49, e-mail: milla.garnyk@gmail.com, https://orcid.org/0000-0003-0983-9323. 
Danchenko Irina Oleksiivna Doctor of Pedagogical Sciences, Associated Professor, Professor of UNESCO "Philosophy of Human Communication" and Social Sciences \& Humanities Department, Head of Psychological Service, Kharkiv Petro Vasylenko National Technical University of Agriculture, 61002, 44 Alchevskih St., Kharkiv, tel.: (095) 515-22-72, e-mail: irinadanchenko@khntusg.info, https^//orcid.org/0000-0003-0103-8142.

Snihurova Irina Ivanivna Philologist, teacher of Ukrainian language and philological disciplines, candidate of UNESCO "Philosophy of Human Communication" and Social Sciences \& Humanities Department, Kharkiv Petro Vasylenko National Technical University of Agriculture, 44 Alchevskih St., Kharkiv, 61002, tel..: (066) 806-60-90, e-mail: irinasnihurova71@gmail.com, https://orcid.org/0000-0002-9637-2428.

Vitkovskyi Yurii Petrovych Doctor of Economic Sciences, Associated Professor, Professor of Marketing \& Economics Department, Vice-Rector for Scientific and Pedagogical Work and International Relations, Kharkiv Petro Vasylenko National Technical University of Agriculture, Affiliated Professor of Academia WSB, 44 Alchevskih St., Kharkiv, 61002, tel.: +38(067)571-60-67, e-mail: vice-rector@khntusg.info, https://orcid.org/0000-0001-5806-8671.

Al-Khalavani Khusameddin Ramazanovych PhD (Political Science), Postdoctoral Student, Kharkiv Petro Vasylenko National Technical University of Agriculture, Head of NGO "Center of international relations "Peace and Security", 13 Office, 14/18 Lipkovskogo St., Kyiv, 03035, tel.: (068)600-95-50, e-mail: husamhalawani@yahoo.com, https://orcid.org/0000-0002-2921-3013.

Sherstyuk Valeryi Serhiiovych PhD (technical sciences), Associated Professor, Corresponding Member of Ukrainian Engineering Sciences Academy, Associated Professor of EEPFP Department, Kharkiv Petro Vasylenko National Technical University of Agriculture, 44 Alchevskih St., Kharkiv, 61002, tel.: (067)242-66-62, e-mail: sherstuk-v-s@ukr.net, https://orcid.org/0000-0002-1781-5009

Osinkin Alexander Oleksandrovych $\mathrm{PhD}$ student, Department of Transport Technologies and Logistics, Kharkiv Petro Vasylenko National Technical University of Agriculture, 44 Alchevskih St., Kharkiv, 61002, tel.: (097)703-60-92, e-mail: aleksander_2020@ukr.net, https://orcid.org/0000-0002-6910-98-86.

\section{COMPETITIVE ABILITY AND DEVELOPMENT OF EDUCATIONAL SERVICES SPECTRUM IN UKRAINE: PEDAGOGYCAL-PSYCHOLOGYCAL ASPECT}

Abstract. Current article continues discussion on key psychological, pedagogical and socio-historical factors of impact on competitive ability and export opportunities of 
educational services provided by national higher education entities, as well as evaluation of impact of national reforms on higher education and reasons for its prestige decline among potential Ukrainian and foreign applicants. Article also represents some of conceptual principles of tolerance building inside educational environment of universities as precondition for social inclusion and internationalization of educational services, as well as development of social and cultural integrative potential of Ukrainian regional higher education institutions according to course of educational reforms and relevant to it transformations on institutional and organizational levels.

Tolerance as an organizational value and virtue of educated person eliminates different kinds of manifestations correlated with intolerant attitude to opinion of others, non-recognition of uniqueness and equality of other people, rejection of their worldview, as well as disregard for human rights. Permanent migration of other cultures representatives to territory of our country causes some citizens to worry and fear about possible restriction of their "national dignity". The variation of this fear spectrum is different: from indifference to aggression, from cold indifference to manifestations of xenophobia (hatred of other nations). From psychological viewpoint such manifestations are considered as kind of hyperbolized protective reaction to real or imagined threats from members of other cultures and / or ethnic groups. Proposed psychological and pedagogical tools will help to reduce socio-psychological stress among participants of educational process and among wider range of national and international stakeholders of educational services.

Keywords: tolerance, socio-cultural integration potential of educational space, quality of education, upbringing of personality.

Постановка проблеми. Історично доведеним $є$ факт того, що розвиток $\mathrm{i}$ заснування університетів у регіональних центрах на теренах України сприяло розбудові міст і зміцненню їх наукового й промислово-технічного потенціалу, зокрема міста Харкова та мережі освітніх установ у ньому [9]. 3 другої половини $\mathrm{XX}$ сторіччя у вищих освітніх закладах міста Харкова набуває практика навчання іноземних громадян, розвиваються педагогічні технології, методики й підходи до підготовки та їх адаптації до навчання в змішаних мультикультурних студентських групах. Проблематика експорту освітніх послуг українськими вишами, оцінки пов'язаних з цим ризиків, підвищення конкурентоспроможності та розширення їхнього спектру стала мультидисциплінарним об'єктом прикладних досліджень, об'єднавши науковців - представників гуманітарних, економічних i технічних напрямів. Актуальність дослідження психологопедагогічних аспектів конкурентоспроможності й розвитку спектру освітніх послуг, зокрема тих, що надаються сьогодні українськими вишами, пов'язана не лише з черговою хвилею національних освітніх реформ, а також із проблемою втрати престижу української вищої освіти серед вітчизняних та іноземних абітуріснтів.

Аналіз останніх досліджень і публікацій. Питання досягнення консенсусу, 
попередження та мирного розв'язання конфліктних ситуацій задля забезпечення мирного співіснування суспільства ще 3 давніх часів окреслили концептуальні рамки кола досліджень, присвячених проблемам взаємоповаги й толерантного ставлення до представників інших спільнот, які на світанку історії людства увійшли до складу релігійних догм, морально-культурних орієнтирів, місцевих звичаїв та згодом і до перших юридичних документів [7, с. 50-55]. На початку XXI сторіччя почало спостерігатися зростання наукового та практичного інтересу представників різних галузей гуманітарних наук до проблеми толерантності й пошуку мирного розв'язання різних типів конфліктів, що виникають у процесі міжкультурного спілкування [26, с. 11-14] та в контексті глобальних соціокультурних і політикоекономічних трансформацій, які торкнулися усіх без винятку соціальних систем. У країнах пострадянського простору зацікавленість цим питанням викликана дестабілізацією соціальних, етнічних, конфесійних i соціальних відносин, загостренням військових протистоянь і міждержавних територіальних конфліктів, наслідком чого стало зростання рівня ворожого ставлення до представників інших культур, певних національностей та етнічних груп [5, с. 4-6]. Тому дослідження феномена толерантності, а особливо його ролі в забезпеченні політичної та соціально-економічної стабільності нашої держави пов'язано сьогодні зі стрімким розвитком європейських демократичних практик і суспільно-політичних інститутів в Україні.

Зазначимо, що термін «толерантність» набув широкого вжитку та популярності в гуманітарних науках і в широкому спектрі соціальних практик, проте, на думку провідних вітчизняних i зарубіжних дослідників, таких як С. Завєтний, С. Пазинич, О. Пономарьов [17], П. Розанволон [15], П. Бателаан [2], Г. Асмолов [1], І. Зязюн [6], Е. Саїд [24], цей термін має широке коло інтерпретацій залежно від історичного та соціально-економічного, культурного й політичного контекстів тієї чи іншої ситуації, у якій його ми вживаємо.

Звертаючись до етимології терміну «толерантність», наразі зазначимо, що вона пов’язана 3 латинським дієсловом «tolero» («нести», «тримати», «витримувати», «терпіти»). Традиційне тлумачення терміну «толерантність»у гуманітарних науках означає ідею міри, ступеню або межі, до якої можна терпіти іншу людину чи явище, навіть за умови, що вони є новими та незрозумілими, що часто стає причиною здивування, несприйняття, ворожого ставлення й опору. Толерантність визначають як «спроможність людини, спільноти, держави дослухатися та поважати точку зору інших, які неворожо зустрічають іншу, відмінну від їхньої, точку зору; готовність та спроможність без протесту сприймати іншу особистість чи явище, прагнути до взаємопорозуміння, поваги до свободи іншого, його/їі світогляду, поведінки, політичних і релігійних поглядів та вподобань» [8, с. 14-16]. Сьогодні поняття «толерантність» стало предметом вивчення не лише гуманітарних наук (медицина, філософія, етика, політологія, педагогіка, теорії міжнародних відносин), а також педагогічної психології, зокрема у вивченні аспектів соціокультурної інтеграції особистості.

Мета статті - висвітлити психолого-педагогічні аспекти формування 
толерантності в освітньому середовищі як запоруки збільшення його інтеграційного (соціокультурна інтеграція, формування колективу тощо), наукового й інноваційно-синергетичного потенціалу, що у свою чергу позитивно впливає на економічні (обсяг коштів від наданих освітніх послуг i коштів, отриманих іншими регіональними суб'єктами від реалізації продукції та надання інших послуг здобувачам вищої освіти в період їх навчання у вишах) й соціальнодемографічні показники розвитку міста та всього регіону в цілому (зниження нестачі висококваліфікованих кадрів на підприємствах, кадрове забезпечення інноваційної діяльності тощо).

Виклад основного матеріалу. Серед багатьох західних теорій розвитку й становлення особистості в мультикультурному суспільстві, з огляду на окреслені нами предмет та об’єкт дослідження, найбільш функціональною, на нашу думку, є епігенетична концепція розвиту особистості, запропонована Е. Еріксоном [27, с. 83]. Вона базується на концептуальних засадах структури особистості, що були розроблені 3. Фрейдом, та являє собою психоісторичну теорію, яка розглядає розвиток особистості через призму впливу на людину конкретного культурного середовища, враховуючи соціокультурну обумовленість психіки й поведінки людини. Згідно ідей Еріксона, кожна наступна стадія розвитку особистості містить відбиток вже набутого досвіду під час проходження нею попередніх етапів становлення. Втім на кожну стадію розвитку особистості накладається матриця соціально-культурних очікувань конкретного суспільства чи спільноти (студентської групи, творчого колективу тощо), тобто певного соціуму-оточення, успіх інтеграції до якого обумовлює ступінь прийняття індивіда тією чи іншою спільнотою, яка представлена у формі формальних i неформальних соціокультурних конструктів, які можуть існувати в таких форматах, як:

- елементи корпоративної культури, інкорпоровані в систему менеджменту якості організації / установи (організаційний рівень);

- законодавство, законодавчі акти й інші нормотворчі документи, правові норми тощо (інституційний рівень);

- притаманні певній спільноті або соціальній групі табу, звичаї, стереотипи, забобони тощо (маргінальний рівень).

Теоретично та на практиці успіх соціокультурної інтеграції особистості корелює безпосередньо 3 рівнем толерантності як індивіда, так і конкретного суспільства або спільноти в цілому. Втім завданням кожного викладача вишу й представників його структурних підрозділів, діяльність яких пов'язана зі спілкуванням із широким колом учасників освітнього процесу та стейкхолдерами освітніх послуг, є розвиток і вдосконалення своїх комунікативних компетенцій із врахуванням аспектів толерантності й етики міжкультурного спілкування. Саме спроможність до побудови та підтримки конструктивного діалогу (аспект соціокультурної медіації) стає сьогодні запорукою успішного розвитку будь-якої організації, колективу, професійної спільноти та суспільства в цілому.

Нашу увагу також привернула запропонована К. Юнгом теорія архетипів, в основі якої лежать універсалізовані типи поведінки («архетипи»), що притаманні 
будь-якій людині або соціальній групі незалежно від конкретних соціокультурних особливостей чи хронологічних рамок періоду, який ми досліджуємо. Подібні універсальні підходи до класифікації поведінкових патернів індивідів ми можемо знайти в соціологічному, культурологоантропологічному чи філософсько-езотеричному доробках як сучасних, так $\mathrm{i}$ давніх мислителів. Проте лише поєднання елементів епігенетичної теорії Еріксона та соціально-антропологічного доробку архетипічних розвідок французького колеги М. Мафесолі сприятиме нам у формуванні системного підходу й розробки методології комплексного дослідження толерантності як запоруки соціальної інклюзії та розвитку (на інституційному чи організаційному рівнях).

Пролити світло на особливості органічного взаємозв'язку між трансформаціями системи освіти в Україні та якістю життя сучасного суспільства ми можемо, звернувшись лише до розробок вітчизняних вчених, зокрема творчого спадку харківського психолога Олександра Костянтиновича Дусавицького. Так, у рамках лекції для аспірантів і молодих викладачів слухачів школи педагогічної майстерності професор О. Дусавицький окреслив основні причини знецінення освіти, підгрунтя їх зародження та подальшої еволюції в соціально-історичному контексті розвитку суспільства.

Етап перший. Знецінення вітчизняної системи освіти історично сягає корінням у часи зародження нового суспільного ладу, носієм якого виступав СРСР (Союз Радянських Соціалістичних Республік), коли під впливом реакційної ідеології розпочалося руйнування системи класичної освіти, яке також супроводжувалося численними репресіями щодо провідних вчених та освітян (їх було проголошено «класовими ворогами», які симпатизували «буржуазній науці»). Так було знищено численні наукові школи в багатьох університетах. У період з 1917 року до 1964 рік поступово набирали силу та впроваджувалися на практиці ідеї рівності всіх членів суспільства (номінальна рівність), що реалізовувалося також у принципах колективізму й надмірній ідеологізації більшості соціально-економічних i гуманітарних галузей науки. Поступово радянська система освіти віддалялася від концептуальних основ і принципів функціонування класичного європейського університету.

Етап другий. Починаючи з 1958 - 1964 років розпочався переломний етап, пов'язаний з освітньою реформою - введенням обов'язкової загальної середньої освіти (з 1 по 10 класи). До цього часу існувала диференціація шкільної аудиторії: до 7 класу навчалися усі школярі, а до 8-10 класів йшли лише здібні учні (приблизно 20\% аудиторії). До вишів зараховували після закінчення 10 класу, тому здобувати вищу освіту прагнули лише мотивовані й талановиті молоді люди, а інші йшли до професійно-технічних училищ, де отримували робітничі професії. Одразу після цієї реформи системи освіти зберігалося співвідношення здібних учнів (15-20\%) до загального контингенту школярів (80-85\%). Проте талановита молодь складала меншість, часто стаючи об'єктами булінгу з боку більш фізично розвинених учнів («спортсменів»). Система освіти поступово 
почала руйнуватися, що також відбилося на спільноті шкільних вчителів. Уже через десять-п’ятнадцять років після згаданої реформи традиційна гендерна рівновага в педагогічних колективах (40\% чоловіків і 60\% жінок) кардинально змінилася: основний контингент шкільних вчителів тепер складали жінки (до 95\%) [12].

У 1964 році випускники шкіл масово почали вступати до вишів, але, згідно результатів дослідження контингенту студентів, у 1980 році здібні студенти складали лише 15\% від загального контингенту студентської молоді. Саме 31980 року набуває розвитку тенденція «відтоку мізків»: провідні вищі залишають викладачі, які поєднували педагогічну діяльність із науково-дослідною роботою. Так почалося руйнування системи освіти та системи цінностей.

Етап третій - «Перебудова», який розпочався у 1985 році. У цей час прийшло до влади нове покоління 35-40 річних випускників закладів вищої освіти, які у кризових ситуаціях часто демонстрували неспроможність приймати логічно-обгрунтовані рішення, системно мислити та оволодівати новими знаннями. Така тенденція швидко укорінилася у всіх соціальних інститутах, особливо у добу, коли нова хвиля науково-технічного прогресу потребувала фахівців з навичками науково-пошукової роботи та засвоєння знань (це можливо лише шляхом розуміння, а не зубріння), спроможних трансформувати теорію в практичні розробки, тому більшість представників цього покоління вдавалася до фальсифікації результатів своїх наукових досліджень, зловживань службовим становищем і поширенням корупційних практик [20].

Етап четвертий - «Невдача реформ системи освіти». Реформа системи освіти передбачала три етапи виховання особистості: молодший шкільний вік (7-9 років) - набуття практичних знань, середній (9-14 років) і старший (14 - 16, 17 років) шкільний вік - набуття наукового знання. Знов поза увагою освітян-реформаторів залишилася необхідність знайомства школярів, починаючи 3 молодшого шкільного віку, з основами наукового теоретичного знання. Тому логічним наслідком експерименту 3 освітньою реформою стала втрата мотивації до навчання та виникнення комплексу неповноцінності в молоді через зміну системи викладання й репрезентації основ наукових знань. На жаль, не всі реформи враховують зміну соціально-історичних умов розвитку суспільства. Цікаво, що в цей же час учасники дванадцятиденного семінару 3 питань реформи системи освіти в Радянському Союзі одностайно дійшли висновку, що наявна система освіти не підлягає взагалі жодному реформуванню [12].

П'ятий етап ознаменувався пошуком нової парадигми, й тому увагу привернула західна (американська) модель системи освіти, де основні ресурси спрямовувалися на виховання еліти суспільства, а більш незначні кошти виділялися на підтримку необхідного мінімального рівня знань (коледжі, середня освіта тощо). Цікаво, що американська концепція передбачала також імпорт наукової еліти за умов нестачі власних наукових кадрів. Прогнози щодо подальшої кризи розвитку та зниження рівня конкурентоспроможної радянської системи освіти були представлені в роботах багатьох вчених того періоду.

Провідні вчені цієї доби, серед яких можна виділити імена О. Леонтьєва, 
Д. Ельконіна, В. Давидова та П. Гальперіна, приділяли увагу вивченню підліткового віку, коли відбувається зміна світогляду. А підліткова агресія (булінг) призводить до збільшення випадків самогубства серед шкільної молоді як своєрідна форма «помсти кривдникам». Криза підліткового віку впливає на подальший розвиток особистості: саме на вік 36 до 10 років припадає формування базових елементів системи цінностей. Саме тому молодший шкільний вік $\epsilon$ найбільш сприятливим для розвитку теоретичного мислення та здобуття основ наукового знання. Цікаво, що саме харківські вчені спростували гіпотезу свого європейського колеги Жана Піаже щодо запропонованої ним періодизації розвитку типів інтелекту особистості. Результати педагогічного лонгітюдного експерименту, який проводився протягом більше ніж двадцяти років у школах № 91 міста Москви та № 17 міста Харкова й був спрямований на вивчення творчих здібностей дитини, було викладено в книзі професора О. Дусавицького «Двічі по два дорівнює Ікс?» [3].

Так, формування теоретичного типу мислення в дітей 6-10 років за методикою «система розвивального навчання» передбачала введення теоретичних знань до програми навчання дітей з першого класу. Педагог формує проблемні завдання, розв'язуючи які учні набувають теоретичних знань, підкріплених практичними навичками 3 природничих, гуманітарних i точних дисциплін. Форма навчання базувалася на колективному розподілі, за яким слідувало індивідуальне сприйняття, відповідно до індивідуальних особливостей кожного учня. Проте такий експеримент зустрів спротив серед ідеологізованих партійних функціонерів і політично заангажованих представників наукової спільноти, бо:

- унаслідок навчання всі учасники експерименту розкрили в собі внутрішню свободу, сформували незалежну систему цінностей, вони перестали боятися зміни професій, сформували та розвинули в собі навички самостійно визначати ризики, ставити й розв'язувати завдання, а також протистояти різного роду деструктивним явищам (інформаційному впливу, соціально-психологічному тиску, булінгу, босінгу тощо);

- чисельність розлучень у родинах колишніх учнів-учасників експерименту дорівнювала $3 \%$ поряд 3 стандартними $50 \%$, бо вони навчилися цінити людей i будувати сталі стосунки, у основі яких лежать взаємодопомога та підтримка;

- колишні однокласники навіть після десятиліть 3 моменту закінчення навчання у школі зберегли та підтримували одне з одним дружні стосунки, а також налагодили конструктивну співпрацю.

Проте, незважаючи на негативне ставлення радянської політичної еліти до результатів педагогічного експерименту професора Дусовицького, його ідеї знайшли подальший розвиток і втілення в розробці педагогічних технологій на основі проблемно-ситуативного принципу навчання студентів, який набув популярності особливо серед викладачів технічних вишів. Утім багато хто 3 колег-викладачів, які стикалися 3 дилемою обрання оптимального сценарію соціокультурної інтеграції здобувачів вищої освіти, зокрема за умови їх навчання 
в мультикультурних студентських групах або при адаптації принципів соціальної інклюзії, вже розроблених для українських шкіл і коледжів, до специфіки викладання профільних дисциплін у технічних університетах, погоджуються, що виховання толерантності як найвищої цінності стає запорукою успішного навчання та конкурентною перевагою (унікальний інклюзивний освітньокультурний простір) вищого освітнього закладу [14, с. 6-7]. Тож розглянемо толерантність та іiі зв’язок із соціокультурною інтеграцією особистості до освітньо-культурного простору закладу вищої освіти.

Традиційно у вітчизняній і зарубіжній літературі соціокультурна інтеграція особистості часто інтерпретується як соціалізація, яка є процесом ії входження в соціальне середовище шляхом оволодіння певними соціальними нормами, правилами, відносинами та цінностями. Однак процеси й результати соціалізації мають діалектичний характер, бо в ідеалі соціалізована людина повинна відповідати соціальним вимогам і водночас протистояти негативним наслідкам тенденцій розвитку сучасного суспільства та життєвим обставинам, що стають перепоною на шляху розвитку іiі індивідуальності. Проте, нерідко зустрічаються люди настільки соціалізовані, фактично розчинені в соціумі, що виявляються неготовими і нездатними до особистої участі в утвердженні конструктивних життєвих принципів та цілей. Значною мірою це залежить від типу виховання та соціального простору, який оточує людину, тому вивченням психологічних аспектів соціокультурної інтеграції особистості займаються переважно фахівці 3 педагогічної та організаційної психології.

Поряд із такими завданнями, як формування й розвиток загальної та професійної культури поколінь, передавання молоді всього багатства надбань матеріальної та духовної культури [10, с. 12], освіта також сприяє формуванню толерантності особистості через цілеспрямований педагогічний вплив, обов'язковий психологічний супровід освітнього процесу.

Зазначимо, що виховання, на відміну від соціалізації, яка відбувається переважно в умовах стихійної взаємодії людини 3 навколишнім середовищем, розглядається як процес цілеспрямованої та свідомо контрольованої соціалізації (сімейне, релігійне, шкільне виховання). Обидва види соціалізації мають ряд відмінностей у різні періоди розвитку особистості. Головна 3 найбільш істотних відмінностей, що проявляються у всіх періодах вікового розвитку особистості, полягає у тому, що виховання виступає механізмом управління процесами соціалізації [18, с. 67].

Тому вихованню властиві дві основні функції: впорядкування всього спектру впливів (фізичних, соціальних, психологічних та ін) на особистість і створення умов для прискорення процесів соціалізації з метою розвитку особистості. Згідно з цими функціями, виховання дозволяє подолати та/або послабити негативні наслідки соціалізації, надати ій гуманістичну орієнтацію, залучити науковий потенціал для прогнозування та конструювання педагогічної стратегії й тактики [10, с. 66-67].

Типи (моделі) виховання зумовлені рівнем розвитку спільнот, їх соціальною стратифікацією та соціально-політичними орієнтаціями. Тому виховання 
здійснюється по-різному в тоталітарному й демократичному суспільствах. У кожному 3 них відтворюються свій тип особистості, своя система цінностей, залежностей і взаємодій, ступенів свободи й відповідальності особистості. У зв'язку з цим виникає питання про ті завдання, які покликана вирішувати цілеспрямована соціокультурна інтеграція особистості, організатором якої $\epsilon$ насамперед педагог або викладач вишу [10, с. 108-109].

Наприклад, А. Мудрик умовно виділив три групи завдань, що вирішуються на кожному етапі соціалізації: природно-культурні, соціально-культурні та соціально-психологічні.

Природно-культурні завдання пов'язані з досягненням на кожному віковому етапі певного рівня фізичного й сексуального розвитку, яка характеризується деякими нормативними відмінностями в тих або інших регіонально-культурних умовах (різні темпи статевого дозрівання, еталони мужності та жіночності в різних етносах і регіонах тощо).

Соціально-культурні завдання - це пізнавальні, етичні, ціннісно-смислові завдання, які специфічні для кожного вікового етапу в конкретному історичному соціумі. Вони визначаються суспільством у цілому, регіональним і найближчим оточенням людини.

Соціально-психологічні завдання, пов'язані зі становленням самосвідомості особистості, іiі самовизначення, самоактуализацией і самоствердженням, які на кожному віковому етапі мають специфічний зміст та способи їх досягнення.

Рішення названих завдань у процесі виховання викликано необхідністю розвитку особистості. Якщо будь-яка група завдань або найбільш значущі $з$ них залишаються невирішеними на тому чи іншому етапі соціалізації, то це або затримує розвиток особистості, або робить іiі неповноцінною [11, с. 65-67].

Дійсно, соціально-психологічні явища, до категорії яких відноситься соціокультурна інтеграція особистості виникають i розвиваються завдяки взаємодії соціокультурного середовища, особистості та групи. Соціальне середовище - це все те, що оточує людину в їі соціальному житті, це конкретний прояв, особливості суспільних відносин на певному етапі їх розвитку. Соціальне середовище залежить від типу суспільних економічних формацій, класової, етнічної та національної приналежності, а також від соціально-психологічних відмінностей самосвідомості та соціальної поведінки представників різних національностей, етнічних груп і верств населення, їх побутових і професійних особливостей. Тобто життєдіяльність людини зумовлена єдністю та взаємодією біологічного й соціального факторів, де головну роль відіграють соціальні фактори [4].

Незаперечним є той факт, що свідомість, мова, культура не передаються шляхом біологічної спадковості, а формуються в людини впродовж іiі життя. Тому в соціально-психологічному аспекті людина $є$ особистістю - соціальнопсихологічною сутністю, що формується внаслідок засвоєння нею соціальних форм свідомості та передачі соціально-історичного досвіду людства безпосередньо під впливом спілкування, виховання, навчання й взаємодії 3 
оточенням. Утім психологія бере до уваги той факт, що особистість виступає не тільки об'єктом соціальних відносин, яка зазнає вплив соціуму, а ще $є$ їх віддзеркаленням. Таким чином, особистість одночасно є і об'єктом, і суб'єктом соціальних відносин, часто виступаючи в ролі сукупності внутрішніх умов, які безпосередньо віддзеркалюють зовнішній вплив соціуму, трансформуючи соціальну систему в цілому. Отже особистість є об'єктом і продуктом соціальних відносин, а також активним суб'єктом діяльності, спілкування, свідомості та самосвідомості. Особистість формується внаслідок культурного та соціального розвитку [25].

Соціалізація особистості є процесом формування особистості в певних соціально-культурних умовах, шляхом засвоєння людиною соціального досвіду, коли людина трансформує здобутий нею соціальний досвід у власні цінності та орієнтації, вибірково інтегруючи до своєї системи поведінки ті норми та шаблони поведінки, які прийняті в тій чи іншій спільноті чи соціальній групі. Втім тут ми маємо дещо зауважити: соціокультурні трансформації суспільства під впливом процесів глобалізації сприяли становленню якісно нового типу особистості - представника «покоління міленіуму» - людини, яка намагається осягнути та реалізувати свій соціокультурний, інтелектуальний і лідерський потенціал, не обмежуючи себе нормами та правилами моралі конкретного суспільства [19, с. 162-163].

Активний рух українських освітніх послуг на міжнародний ринок i підготовка конкурентоздатних іноземних фахівців вимагає організації процесу адаптації студентів до нового соціуму, його культури, навчально-інформаційного професійно зорієнтованого середовища вишів. Зважаючи на зазначене, адаптація стає все більш актуальною педагогічною проблемою, зумовленою соціокультурною та психолого-педагогічною своєрідністю іноземних студентів. Адаптивним проблемам іноземних студентів значну увагу приділяли в дослідженнях зарубіжні та вітчизняні соціологи, соціальні психологи та педагоги (М. Вебер, А. Корміліцин, О. Михайлова, О. Скворцова, П. Сорокін, О. Суригін, С. Бокнер, К. Оберг, Г. Триандіс та інші). Для популяризації наукових здобутків дослідження проблем оптимізації процесу міжкультурної взаємодії та соціокультурної інтеграції в 1977 році було засновано «Міжнародний журнал міжкультурних відносин», а також професійна асоціація «Товариство міжкультурних відносин». Першість у розробці навчальних програм у царині міжкультурних відносин для різних категорій слухачів (студентів, військовослужбовців, туристів, державних службовців) належить американськими соціальним психологам і соціологам. На початку XXI сторіччя проблема міжкультурних відносин та формування толерантності отримала новий поштовх для більш докладного та системного вивчення через зростання експорту освітніх послуг (одного з пріоритетних напрямів розвитку національної вищої освіти) та інтернаціоналізацію освіти, яка ініціює формування й/або оптимізацію механізмів соціокультурної інтеграції та їх психологічного супроводу.

Загальновідомо, що до елементів будь-якого соціокультурного середовища належать традиції, норми та цінності культури; створена певним суспільством 
система соціально-культурного обслуговування (засоби переробки, передачі інформації, форми та способи культурно-інформаційного обміну й організації діяльності, а також механізми залучення людей до соціокультурної взаємодії, соціальні інститути та громадські об'єдання); спосіб життя населення; нормативно-регулятивні структури суспільства.

Потрапивши до нового соціокультурного середовища, особистість має пройти шлях соціокультурної адаптації, внаслідок якого людина досягає гармонії 3 новим соціальним і культурним середовищем. Результатом даного процесу $\epsilon$ почуття задоволеності й повноти життя та залучення до соціального й культурного житті нової групи. Соціокультурна інтеграція особистості також $\epsilon$ процесом входження в новий соціум і нову культуру (субкультуру) шляхом поступового засвоєння їі норм, цінностей та патернів поведінки. Соціокультурна адаптація припускає досягнення соціальної й психологічної інтеграції 3 ще однією культурою без втрати надбань власної [21, с. 478-481].

Крім адаптаційних труднощів, спільних для іноземців незалежно від країни їх перебування, також у мігрантів часто виникають специфічні складні моменти в процесі соціокультурної адаптації, зумовлені унікальністю того соціуму, до якого вони потрапили. Проте під час проведення порівняльного дослідження патернів соціально-економічної поведінки представників ліванської діаспори в Україні [22, с. 190] було виявлено характерні риси соціокультурної інтеграції, притаманні будь-якій особистості, яка потрапляє за межі свого соціально-культурного простору (наприклад, своєї країни). Ці риси збігаються з теорією М. Мафессолі щодо архетипіки племені [23]. Викладене вище зумовлює ключову роль психологічної служби вишу в управлінні процесом соціокультурної інтеграції здобувачів вищої освіти, до якого залучаються також інші структурні підрозділи вишу, діяльність яких безпосередньо пов’язана із окресленим нами вище питаннями.

Корпоративна культура вишу, як соціально-інтеграційний інститут, передбачає формування та розвиток механізмів і стратегій залучення, соціальнопсихологічної інклюзї та розвитку особистості в колективі. Щодо розвитку та культивації засад толерантності в освітньо-культурному просторі вишу, то передусім треба обрати та впровадити методи психологічної діагностики, які спрямовано на виявлення в учасників освітнього процесу схильностей до проявів інтолерантності, що безпосередньо пов'язано із ризиком розв’язання та розвитку тривалих конфліктів у колективі.

На нашу думку, у закладах вищої освіти доцільно запровадити процедуру систематичного дослідження аспектів толерантності, у основі якої повинні міститися вивчення психологічних аспектів теорії міжкультурної комунікації, елементи соціальної антропології й етнопсихології. Підбор методів і методик дослідження зазвичай визначає принцип системності, що передбачає вивчення предметів і явищ реальності в їх суттєвих взаємозв'язках і взаємозалежностях. Такий принцип вимагає розгляду об’єкту дослідження як цілісного явища, а також виокремлення його структурних елементів, взаємозв’язків, якими 
характеризуються особливості цього об’єкта та його вивчання як частини більшої структури, а також і взаємозв'язку між ними [14].

Саме тому дослідження толерантності особистості потрібно проводити 3 урахуванням положень системного підходу, а як метод емпіричного дослідження, на нашу думку, більш доцільним буде стандартизоване опитування в дистанційній формі, що є універсальним методом, який дозволяє автоматизувати збір та обробку великого обсягу даних за невеликий проміжок часу, забезпечуючи валідність вибірки. Перевагою цього методу $є$ також легкість застосування й обробки даних. Для дослідження кожного рівня системи толерантності ми пропонуємо застосовувати відповідні методики: методика діагностики загальної комунікативної толерантності (В.В. Бойко), експрес-тест «Індекс толерантності» (Г. У. Солдатова), методика діагностики типу етнічної ідентичності (варіант Г. У. Солдатової та С. В. Рижової), методика визначення соціокультурної ідентичності (ОСКІ); шкала соціальної дистанції (шкала Е. Богардуса) (варіант Л. Г. Почебут); визначення життєвих цінностей MUST-TEST (варіант П.М. Іванова, Є. Ф. Колобової). Аналізуючи отримані результати комплексного дослідження толерантності, психологічна служба нашого університету розробляє тренінги для учасників освітнього процесу (здобувачів вищої освіти, викладачів і персоналу структурних підрозділів), а також узгоджує з вищим керівництвом закладу освіти стратегію розвитку потенціалу соціально-культурної інтеграції освітнього простору закладу вищої освіти. Ці заходи та процедури традиційно входять до системи управління якістю освіти як запорука розбудови корпоративної культури та цінностей кожної успішної організації [13].

Висновки. Як бачимо, сьогодні в українському суспільстві, на жаль, досі простежуються прояви інтолерантного ставлення до думки інших, невизнання унікальності та рівноцінності інших людей (гендерна рівність тощо), несприйняття світогляду інших людей (етно-конфесійна ворожість), а також неповага до прав людини. Постійна міграція представників інших культур на територію нашої країни викликає в деяких наших співгромадян занепокоєння та страх перед можливим обмеженням їх «національної гідності». Відтінки цього побоювання різні: від індиферентності до агресії, від холодної байдужості до виявів ксенофобії (ненависті до представників іншої нації). 3 точки зору психології такі прояви розглядаються як своєрідна гіперболізована захисна реакцію на реальні або уявні загрози з боку представників інших культур та/або етнічних груп. У будь-якому випадку людина не повинна забувати те, що вона $\epsilon$ такою ж самою унікальною особистістю, як і інші, а тому вона не має ніякого права на злість, ненависть, обмеження законних прав інших людей.

Зміст освіти має історичний характер, який визначається цілями й завданнями освіти на тому чи іншому етапі розвитку суспільства. Це означає, що він змінюється під впливом вимог життя, виробництва та рівня розвитку наукового знання. Провідною детермінантою змісту освіти $є$ īi мета, яка відображує в повній мірі як інтереси суспільства, так й інтереси особистості. Тому метою сучасної української освіти є розвиток тих властивостей особистості, 
які потрібні їй та суспільству для іï інкорпорації та/або інтеграції (у випадку іноземців чи представників діаспор) до українського соціально-культурного середовища для залучення їі до суспільно корисної діяльності. Ступінь цього розвитку визначає ставлення до знань, умінь і навичок як до засобів досягнення повноцінного, гармонійного формування емоційної, розумової, ціннісної, вольової та фізичної сторін людини. Тому отримання якісної освіти й корисних знань, вмінь, а також формування толерантності та розвиток комунікативних навичок, стають визначальною умовою для досягнення людиною успіху в житті, збереження ідентичності та культури свого народу [16; 25]. Саме ці аспекти впливають на конкурентоспроможність освітніх послуг, бо сприяють розвитку особистості кожного здобувача вищої освіти, розвиваючі його або іiі творчій потенціал, навички співпраці у мультикультурному колективі, а також адаптацію до умов середовища іншої культури.

Психологічний супровід освітнього процесу, гуманітарний цикл наук i вивчення основ мистецтва (естетичне виховання) у вищих освітніх закладах та установах є засобами формування толерантності особистості, а також засвоєння методів пошуку й перевірки істини, пізнання та розвитку відчуття прекрасного, бо людина $\epsilon$ динамічною соціокультурною системою, яка формується як особистість лише в процесі взаємодії 3 навколишнім середовищем. Перспективним напрямком розвитку психологічного супроводу освітнього процесу наразі є проведення тематичних тренінгів у форматі онлайн та офлайн дистанційних модулів, які можуть бути як частиною певних дисциплін, так і самостійними освітніми модулями, за проходження яких учасники освітнього процесу отримуватимуть заохочення, наприклад, у вигляді додаткових рейтингових балів тощо.

\section{Лimepamypa:}

1. Асмолов А. Г. Толерантность: различные парадигмы анализа. Толерантность в общественном сознании России. Москва: Смысл, 1998. 246 с.

2. Бателаан П. Межкультурное образование - больше, чем долг. Москва:Просвещение, 2002. $243 \mathrm{c}$.

3. Дусавицкий А. К. 2 х 2=X? Харьков: 2002. 172 с.

4. Дусавицкий А. К. Развитие личности в студенческом коллективе в зависимости от сформированности учебно-профессиональных интересов: учебно-методическое пособие. Харьков: ХНУ имени В. Н. Каразина, 2012. 32 с.

5. Злочини на підгрунті ненависті в Україні. Серпень 2013 - грудень 2014 / за ред. В. М. Бацунов; ГО «Харківська правозахисна група». Харків: Права Людини, 2014. 500 с.

6. Зязюн I. А. Педагогіка добра: ідеали та реалії: науково-методичний посібник / за ред. І. А. Зязюн, Л. В. Карамущенко, І. Ф. Кривонос та ін. Київ: Вища школа, 1997. 349 с.

7. История политических учений / под. ред. С. Ф. Кечекьяна и Г. И. Федькина. Издание второе. Москва: Государственное издательство юридической литературы, 1960. 893 с.

8. К толерантности шаг за шагом: учеб. пособие для учащихся / под ред. Н. И. Элиасберг, Г. А. Сунгурова, Д. А. Нерознак. Питер: «Перспектива:Союз», 2008. 203 с.

9. Краткий очерк истории Харьковского университета за первые сто лет его существования (1805-1905) / под ред. Д. И. Багалей, Н. Ф. Сумцов, В. П. Бузескул. - Харьков: Типография Адольфа Дарре, 1906. 329 с. 
10. Культура педагога: монографія / С. О. Завєтний, С. М. Пазинич, О. С. Пономарьов, Л. М. Тищенко. За ред. О. С. Пономарьова. Харків: «Міськдрук», ХНТУСГ імені П. Василенка, 2015. $320 \mathrm{c.}$

11. Мудрик А. В. Социализация человека: учебное пособие. Москва: Издательский центр «Академия», 2004. 304 с.

12. Полотебнов А. С. Образовательная реформа 1958-1964 годов: Ленинградский опыт реализации. Человек и образование, 2017. №1 (50). С. 127-131.

13. Психологічна служба ХНТУСГ імені П. Василенка. Офіційний сайт ХНТУСГ імені П. Василенка. URL: https://khntusg.com.ua/unit/5-2/. (Дата звернення: 21.08.2021).

14. Психологія студентської групи. На допомогу кураторам. / Укладачі: Л. М. Яворовська, Т. О. Чугуй, М. І. Філон. Випуск 2. Харків: ХНУ імені В. Н. Каразіна, 2009. 84 с.

15. Розанволон П. Демократична легітимність. Безсторонність, рефлективність, наближеність / переклад 3 франц. Є. Марічева. Київ: Видавничий дім «Києво-могилянська академія», 2009. 287 с.

16. Стратегія розвитку вищої освіти в Україні на 2021-2031 роки. МОН України, 29 травня, 2020. URL: https://rozvitku-vishchoi-osviti-v-ukraini-02-10-2020.pdf. (Дата звернення: 17.07.2021).

17. Філософія спілкування: монографія / В. Г. Кремень, Д. І. Мазоренко, С. О. Завєтний, С. М. Пазинич, О. С. Пономарьов. Харків: ХНТУСГ ім. П. Василенка, 2011. 440 с.

18. Філософія управління: Підручник для студентів вищих навчальних закладів / В. Г. Кремінь, С. М. Пазинич, О. С. Пономарьов. Київ: Знання України, 2007. 360 с.

19. Culter A. Leadership psychology: How the best leaders inspire their people. London: Cogan Page, 2014. 283 p.

20. Denisova-Schmidt E., Prytula Y. Ukraine: Endemic Higher Education Corruption. International Higher Education. Vol. 90 (2017), pp.16-18. DOI:10.6017/ihe.2017.90.10000

21. Friedman T.L. The world is flat 3.0: A brief history of the twenty-first century. New York: Picador, 2007. 672 p.

22. Garnyk L. P., Yaghi M.M. Archetypes of economic behavior and their origins in scientificphilosophic thought of middle Eastern countries. Публічне управління. № 3 (8), червень 2017. Київ: ДП «Видавничий дім «Персонал», 2017. С. 178-193.

23. Maffesoli M. The Time of the Tribes: The Decline of Individualism in Mass Society. London: SAGE, 1996. 176 p.

24. Power, politics and culture: interviews with Edvard W. Said / Edited and with introduction of Gauri Viswanathan. London: Bloomsbury, 2004. 485 p.

25. Social inclusion. URL: https://www.worldbank.org/en/topic/social-inclusion\# (Accessed: 28 March, 2021).

26. Thomas M. S. The global resurgence of religion and the transformation of international relations: The struggle for the soul of the twenty-first Century. New York: Palgrave Macmillan, 2009. 300 p.

27. Zock H., Zock T. A psychology of ultimate concern: Erik H. Erikson`s contribution to the psychology of religion. New York: Rodopi, 2004. 258 p.

\section{References:}

1. Asmolov A. G. (1998). Tolerantnost': razlichnye paradigmy analiza. [Tolerance: different paradigms of analysis]. Tolerantnost' $v$ obshhestvennom soznanii Rossii (Tolerance in public consciousness of Russia). Moskva: Smysl [in Russian].

2. Batelaan P. (2002). Mezhkul'turnoe obrazovanie - bol'she, chem dolg [Intercultural education is more than a duty]. Moskva: Prosveshhenie [in Russian].

3. Dusavickij A. K. (2002). 2 x 2=X? Kharkiv: n.d. [in Russian].

4. Dusavickij A. K. (2012). Razvitie lichnosti v studencheskom kollektive v zavisimosti ot sformirovannosti uchebno-professional'nyh interesov: uchebno-metodicheskoe posobie [Personality 
development in student community depending on educational and professional interests formation: a textbook]. Har'kov: HNU imeni V. N. Karazina [in Russian].

5. Bacunov V. M. (Eds.). (2014). Zlochyny na pidhrunti nenavysti v Ukrayini. Serpen' 2013 -hruden' 2014 [Hate crimes in Ukraine. August, 2013 - December, 2014]. HO «Xarkivs'ka pravozaxysna hrupa» (Kharkiv Human rights protection group). Xarkiv: Prava Lyudyny [in Ukrainian].

6. Zyazyun I. A. (Eds.) et. al. (1997). Pedahohika dobra: idealy ta realiyi: naukovo-metodychnyj posibnyk [Pedagogy of good: ideals and realities: scientific and methodical manual]. Kyyiv: Vyshha shkola [in Ukrainian].

7. Kechek'yan S. F. \& Fed'kyn H. Y. (Eds.). (1960). Ystoryya polytycheskyx uchenyj [History of political doctrines]. Yzdanye vtoroe - Second edition. Moskva: Hosudarstvennoe yzdatel'stvo yurydycheskoj lyteratury [in Russian].

8. Jeliasberg N. I., Sungurova G. A. \& Neroznak D. A. (Eds.). (2008). K tolerantnosti shag za shagom: ucheb. posobie dlja uchashhihsja [To tolerance step by step: handbook for students]. Piter: «Perspektiva: Sojuz» [In Russan].

9. Bagalej D. I, Sumcov N. F. \& Buzeskul V. P. (Eds.). (1906). Kratkij ocherk istorii Har'kovskogo universiteta za pervye sto let ego sushhestvovanija (1805-1905) [A brief observe of the history of Kharkov University in the first hundred years of its existence (1805-1905)]. Har'kov: Tipografija Adol'fa Darre [in Russian].

10. Ponomar'ov O. S. (Eds.). (2015). Kul'tura pedahoha: monohrafiya [Teacher's culture]. S. O. Zavyetnyj, S. M. Pazynych, O. S. Ponomar'ov, L. M. Tyshhenko (Ed.). Xarkiv: «Mis'kdruk», XNTUSH imeni P. Vasylenka [In Russian].

11. Mudryk A. V. (2004). Socyalyzacyya cheloveka: uchebnoe posobye [Human socialization: study guide]. Moskva: Yzdatel'skyj centr «Akademyya» [In Russian].

12. Polotebnov A. S. (2017). Obrazovatel'naya reforma 1958-1964 hodov: Lenynhradskyj opyt realyzacyy [Educational reform 1958-1964: Leningrad implementation experience]. Chelovek $y$ obrazovanye - Human and Education. Vol. \# 1(50), 127-131 [in Russian].

13. Psyxolohichna sluzhba XNTUSH imeni P. Vasylenka. Oficijnyj sajt KhNTUSG imeni P. Vasylenka [Psychological service of P. Vasylenko KhNTUSG. Official web-site of P. Vasylenko KhNTUSG]. khntusg.com.ua/unit/5-2/. Retrived from: https://khntusg.com.ua/unit/5-2 [in Ukrainian].

14. Yavorovs'ka L. M., Chuhuj T. O. \& Filon M. I. (Eds.). (2009). Psyxolohiya students'koyi hrupy. Na dopomohu kuratoram [Psychology of student groups. For help to curators]. Vol. \#2. Xarkiv: XNU imeni V. N. Karazina [in Russian].

15. Rozanvolon P. (2009). Demokratychna lehitymnist'. Bezstoronnist', reflektyvnist', nablyzhenist' [Democratic legitimacy. Independence. Reflectivity. Closeness]. (Ye. Maricheva, Trans.) Kyyiv: Vydavnychyj dim «Kyyevo-mohylyans'ka akademiya» [in Ukrainian].

16. MON Ukrainy (29.05.2020). Stratehiia rozvytku vyshchoi osvity v Ukraini na 2021-2031 roky [Strategy of higher education development in Ukraine during 2021-2031]. www.mon.gov.ua. Retrieved from: https://rozvitku-vishchoi-osviti-v-ukraini-02-10-2020.pdf. [in Ukrainian].

17. Kremen V. H., Mazorenko D. I., Zavietnyi S. O., Pazynych S. M. \& Ponomarov O. S. (Eds.). (2011). Filosofiia spilkuvannia: monohrafiia [Philosophy of communication: monograph]. Kharkiv: KhNTUSG im. P. Vasylenka [in Ukrainian].

18. Kremen V. H., Pazynych S. M. \& Ponomarov O. S. (Eds.) (2007). Filosofiia upravlinnia: Pidruchnyk dlia studentiv vyshchykh navchalnykh zakladiv [Philosophy of management: A textbook for students of higher educational institutions]. Kyiv: Znannia Ukrainy [in Ukrainian].

19. Culter A. (2014). Leadership psychology: How the best leaders inspire their people. London: Cogan Page.

20. Denisova-Schmidt E. \& Prytula Y. (2017). Ukraine: Endemic Higher Education Corruption. International Higher Education. Vol. 90 (2017), 16-18. DOI:10.6017/ihe.2017.90.10000.

21. Friedman T.L. (2007). The world is flat 3.0: A brief history of the twenty-first century. New York: Picador. 
22. Garnyk L. P. \& Yaghi M.M. (2017). Archetypes of economic behavior and their origins in scientific-philosophic thought of Middle Eastern countries. Публічне управління. № 3 (8), 178-193.

23. Maffesoli M. (1996). The Time of the Tribes: The Decline of Individualism in Mass Society. London: SAGE.

24. Viswanathan G. (Eds.). (2004). Power, politics and culture: interviews with Edvard W. Said. London: Bloomsbury.

25. Social inclusion (n.d.). www.worldbank.org. Retrieved from: https://www.worldbank.org/en/topic/social-inclusion\#

26. Thomas M. S. (2009). The global resurgence of religion and the transformation of international relations: The struggle for the soul of the twenty-first Century. New York: Palgrave Macmillan.

27. Zock H. \& Zock T. (2004). A psychology of ultimate concern: Erik H. Erikson's contribution to the psychology of religion. New York: Rodopi. 